\title{
Spiritual Care as the Foundation for a Child's Religious Education
}

\author{
Joyce E. Bellous
}

Citation: Bellous, Joyce E.. 2021. Spiritual Care as the Foundation for a Child's Religious Education. Religions 12: 954. https://doi.org/10.3390/ rel12110954

Academic Editors: Richard Woolley and Ellie Hill

Received: 9 September 2021

Accepted: 26 October 2021

Published: 2 November 2021

Publisher's Note: MDPI stays neutral with regard to jurisdictional claims in published maps and institutional affiliations.

Copyright: (C) 2021 by the author. Licensee MDPI, Basel, Switzerland. This article is an open access article distributed under the terms and conditions of the Creative Commons Attribution (CC BY) license (https:/ / creativecommons.org/licenses/by/ $4.0 /)$.
Christian Faith Education, Taylor Seminary, Edmonton, AB T6J 4T3, Canada; joycebellous@gmail.com

\begin{abstract}
This article outlines spiritual care as the foundation for a child's religious education. The elements of spiritual care are described by identifying how God concepts form in the young, by naming children's inherent spiritual needs, by offering perspectives from human spirituality research over the last 60 years, particularly as it applies to children, by analyzing the way meaning forms through experience as it finds its way into worldviews each of us holds by early adolescence, and finally, by depicting four types of literacy (cognitive, emotional, imaginative and social) at the basis of spiritual care and as the groundwork for a child's future development within various religious traditions. The purpose of spiritual care is to focus on the humanity of children and to situate their education within a framework built on their spiritual needs. This article is deeply embedded in assumptions associated with the Christian tradition. However, a fundamental assumption of spirituality research is that every person is spiritual. As a result, the intention to educate the human spirit as a first step to initiating children into a faith tradition is well founded; it also raises the possibility of spiritual care as undergirding secular education, but that question is beyond this article's purview. The intention is to spark a conversation among religious traditions as one way to meet the deepest spiritual needs of children, which is an urgent dialogue to engage in at present. If French philosopher Jean Baudrillard was correct, the age we are living in is well described as a revolution of confusion. A response to confusion requires [meeting] the spiritual needs of children and creating a broad theoretical and practical approach to how they think and act, as they move into a tradition that they take on board, along with their developed capacity to reflect on that tradition from personal and socially informed perspectives.
\end{abstract}

Keywords: children's spirituality; spiritual care; religious education; worldview formation; conceptual learning; cognitive literacy; emotional literacy; imaginative literacy; social literacy

\section{Introduction}

Children want to talk about what really matters to them. They need to be with adults who listen and observe. This ought not to be a surprise. The first well known philosopher to seriously consider how to educate children was Socrates (Plato 1956). He was very clear about listening to children and observing them carefully as the first step to discovering how to teach them. In his gold, silver, bronze analogy, he made a culturally disturbing assertion that when children become adults, they should take on work they show an aptitude for while they are young. The implication of his insistence that we first observe the child left the wealthy without assurance that their children would follow in the footsteps of family privilege. Socrates was not popular; but he was, of course, correct.

This article outlines elements of spiritual care that undergird a child's religious education as one way to follow Socratic insights about teaching. The spiritual care of children is focused on listening to them, observing them, understanding how thinking itself works, and meeting their spiritual needs. The article introduces spiritual care by identifying how God concepts form in the young, by naming children's inherent spiritual needs, by describing features of human spirituality based on its research over the last 60 years, particularly as it applies to children, by analyzing the way meaning forms through experience as it finds 
its way into worldviews each of us holds by early adolescence, and finally, by depicting four types of literacy (cognitive, emotional, imaginative and social) that are indicative of spiritual care and are the groundwork for a child's development within various religious traditions. The article's purpose is to focus on the humanity of children and build religious education on their spiritual needs by attending to personal worldviews that continue to shape their life experiences.

The article is deeply embedded in assumptions associated with Christian tradition. However, a fundamental assumption of spirituality research is that every person is spiritual. As a result, the intention to educate the human spirit as a first step to initiating children and youth into a faith tradition is well founded; it also raises the possibility of spiritual care as undergirding secular education, but that question is beyond the article's purview. The intention is to spark a conversation among religious traditions as one way to meet the deepest spiritual needs of children, which is an urgent dialogue to engage in at present. If French philosopher Jean Baudrillard was correct, the age we are living in is well described as a revolution of confusion (Baudrillard 1993; Bellous 1996). A response to confusion requires that adults address the spiritual needs of the young and create a broad theoretical and practical approach to how they think and act, as they move into a tradition that they take on board, along with their developed capacity to reflect on that tradition from personal and socially informed perspectives.

\section{Forming God Concepts}

American psychoanalyst Ana-Maria Rizzuto studied the theory of object relations which Sigmund Freud uncovered. Freud (1961) wanted to know how people come to possess an actual belief in the existence of God (Rizzuto 1979). His theory of object relations answered that question. As with all theories, object relation theories are limited to what we can observe of human experience. While it is limited, observing human phenomena remains a plausible way to make the human experience more understandable, bearable and open to transformation. What is strange about Freud's theory is his elimination of mothers from the formation of God concepts. Rizzuto addressed his omission and its significance to God concept formation (Rizzuto 1979, 1998). British psychologist John Bowlby (1988) also addressed Freud's omission by describing attachment theory, which is an interpretation of object relations interaction (usually) between mother and child. For the most part, twentieth century infant research was carried out with mothers and infants, although in this century, there is a growing body of research between fathers and infants (Clinton 2020).

In general, object relation theories explain our need for others, because they are "theories about our relations to the 'objects' - people and things- to which we are attached and which give meaning to our lives" (Klein 1987). In writing about them, Rizzuto's aim was to demonstrate how object relations theories illuminate the formation of God concepts. She also points to limitations in the way Freud applied his theory. Hers is not a book on religion; rather, it asserts that religious education must acknowledge the mental mythologies (worldview) each child brings to the classroom. The relation between meaningful objects and the formation of God concepts can be examined, first by exploring Rizzuto's views and then by considering Bowlby's attachment theory. The purpose of this section is to explicate what it means to hold a God concept and to hold on to it over time.

To begin with, the term God concept designates a union of ideas, feelings and images each person associates with God. Images and ideas are acquired early in life: the "first conscious God representations appear between the ages of two and three" (Rizzuto 1979). A concept of God blends feeling-charged images with intellectually rich ideas to form a concept that has cognitive as well as affective dimensions. Rizzuto asserts that every human being constructs a concept for God, so that there is no such thing as a human being without a God concept. She proposes that "each individual produces an idiosyncratic and highly personalized" concept derived from object relations, evolving self-representations, 
and environmental systems of belief; further, once formed, a God concept "cannot be made to disappear; it can only be repressed, transformed or used" (Rizzuto 1979).

God concepts form in a space carved out between mother and infant in their mutual relationship. This middle space becomes an important idea in the section on four types of literacy, particularly in the explication of imaginative literacy. Forming God concepts depends on an "early stage in this development ... made possible by the mother's special capacity for making adaptation to the needs of her infant, thus allowing the infant the illusion that what the infant creates really exists" (Rizzuto 1979). Mental health is impacted by the strength of childhood self-confidence arising through this development.

God concepts form in a space between infant and mother that is its own reality and that contributes to a child's sense of being real and living in a real world. This space of experiencing is located between two elements necessary for normal functioning: an inner psychic or soul reality, which we tend to situate in the mind, head, belly, heart or some other physical part of the body, as a simple way to express its identity and explain its function, and an external reality-the people and objects outside the psychophysical entity we call a human being. Experience takes place in the 'space' between mother and child (Winnicott 1971) and it is a place with the potential to house healthy illusions about life.

German-American psychologist Erik Erikson (1950) elaborated what happens in these encounters between infant and mother, in terms of the development of trust or its deficiency. Trust forms primarily through one's experience of parental attentiveness. Due to the very human potential involved in the child/parent relation, "attention is the central reinforcement of [that] sensory process" (Klein 1987) through their gaze behavior-an interaction that has no need for words (of which an infant is incapable). Attention is linked to expectation; if conditions are favorable, and if the mother consistently (although not slavishly) meets her child's needs, the child develops a sense of what experience is like and that it is pleasant. American psychiatrist Daniel Stern (1985) identifies in these encounters what he calls the building of trace memories, which are representations of interactions that have been generalized, which he refers to as RIGs. Children register a trace memory of their mother with a general sense that she responds to needs in a way that is pleasant. As Stern points out, the need for repetition of these interactions for trace memories to form may relieve parents who sometimes worry that infants are irreversibly harmed by even a very few of their inappropriate responses (Stern 1985).

Like Stern, Rizzuto was interested in children's subjective experience, an unconscious weaving of images, feelings and ideas that converge in the process of elaborating a concept for God (Rizzuto 1979). She found that representational memories, woven together to form the concept of self that is based on one's objects, are retrievable, so that a child can reassure itself in times of lowered self-esteem and they can be used to enhance an existing feeling of self-worth (Rizzuto 1979). As one example of this type of self-support, a young boy may briefly twine his hair around his finger as he unknowingly remembers his mother caressing his hair as her typical way of comforting him. Rizzuto's research is evidence for a correlation between an experience of one's parents and one's view of God, through her carefully constructed case histories. God is, in this sense, an ultimate parent who is viewed as highly capable of meeting needs, of being loving and able to provide consolation and protection, or else, God is viewed as entirely incapable of providing necessary resources for living. Rizzuto was interested that Sigmund Freud chose to see God as incapable of providing essential life resources (Rizzuto 1998).

She made a careful study of his reasons for rejecting God, and in doing so, provides more clues to the significance of object relations in the formation of God concepts (Rizzuto 1998). She is clear: God concepts remain entwined in a complex way with one's experience of parents, as Freud's case reveals (Rizzuto 1998). God concepts may be repressed or transformed but they do not go away. Children learn through experience to trust or mistrust God. Parents, teachers, significant others, sanctuaries that house religious communities, and television programs, as some examples, influence a child's notion that God is dependable, good, kind, or is the opposite, even children with no religious training. 


\section{Learning as Organizing Experience}

The spiritual development of children is a consequence of the formation of meaning made from infancy onward. When children (even those with no experience of religion) are asked to give an account of God, they may do so in words or by drawing a picture. During research into spirituality, the young demonstrate readiness to use religious language to express spiritual insight. As an example, Katie (age 6) told British researcher Rebecca Nye that she had recently become the owner of a Bible but said she had never been inside a church. Rebecca asked her what she thought about God, and Katie replied: "I don't know yet, because I haven't read it very long". Question: "Did you know about God before you got your Bible?" Response: "No, not at all". Katie had little coherent understanding of formal religion. However, early in this same conversation, she told Rebecca, when discussing a picture of a starry sky, "You couldn't even reach that high, no one can except God". At another point in the conversation, when asked what sort of things someone could know about themselves that nobody else could know, Katie replied: "God knows everything". At another moment, reflecting on how we know things, she said that her moral knowledge of when she was being good or bad was God-given. In addition, she decided that other kinds of knowledge are beyond human understanding, but might be special knowledge, available to God, such as the mystery of "like ... um ... how we get alive" (Hay and Nye 1998).

Katie's story is not unique. People who have no formal religious training have a concept for God, a phenomenon repeated in other research, as far back as William James's exploration in The Varieties of Religious Experience (James 1971) and in the work of American author Robert Coles (1989), in his book, The Call of Stories. God concepts form in an intermediate 'space' between infants and the outside world. In this location, between the inner and outer reality, meaning is created. This third place, which is neither the self nor the world but is influenced by both, is the genesis of the spiritual aspect of human life. The spiritual is an intermediate space between the personal and the material. It is a mid-point reality between subjective and objective realities. Objects form here as a child experiences the self and the world. These objects focus a child's ongoing perceptions of everything. The intermediate space is an area of experiencing, "to which inner reality and external life both contribute", and which, in turn, acts back on a child's perception and understanding of outer and inner reality. It is an unchallenged space that an individual creates in the "perpetual human task of keeping inner and outer reality separate yet interrelated" (Winnicott 1971).

The spiritual aspect of human beings integrates experience and forms embodied concepts we live by. These embodied, emotionally laden concepts can shift their shape with changes in experience. Keeping up with new experiences is a spiritual task. Mental health depends upon the activity of interrelating yet separating material and personal realities implied in experiencing, i.e., this place of illusions. In the sense used here, illusion does not signify something false. Illusion is not delusion. All art, science and religion depend on illusion for their existence. Illusion is the bedrock of learning because all learning is the organization of lived experience. In this intermediate space, organizing happens. These illusions are not false so much as they are idiosyncratic and useful as organizing principles for life. Over time, we are called on to test the world and ourselves based on illusions formed early in life. Illusions (representations or concepts) that flourish in the intermediate space between self and world and are called "transitional phenomena" (Winnicott 1971) or transitional objects. These objects (image/feeling/idea) are the stuff of thinking; they are experience-rich and assumption-laden. God concepts are transitional objects in this sense.

Transitional objects, formed in the margins between inner personal experience and outer material reality, explicate the Judeo/Christian assertion that we are made in God's image. Perhaps it was the concept Cain had for God that prevented their intimacy, just as his brother Abel's God concept allowed him to offer an acceptable sacrifice. It is striking that God met Cain in his resentment and tried to open his experience up to hope. Cain did not accept the invitation; instead, he killed his brother. Cain's pattern is oft repeated. It is 
as if Cain could choose to reconsider his idea of God, or sin. He did not seem to hear what God was offering (Genesis 4:1-16). This is sin's educational role-although its lessons often come at a high human cost. From this traditional perspective on the way life educates us, spiritual maturity is not accomplished solely by acts of the will. Rather, it is accomplished through experiencing, by seeing and hearing God's own way of being so that we test our assumptions about God, our inadequate, confused, incomplete understandings, against the reality of God's way of being, at least from a traditional perspective on the Genesis account. Spiritual maturity is a by-product of seeing God in new ways, as Job (in contrast to Cain) testified at the end of his suffering and as a result of it (Job 42:1-6).

The psychological idea of 'experiencing' is like the philosophical concept of experiencing described by Hegel and used educationally by American philosopher John Dewey. Dewey described experiencing in his book, Art as Experience. He was concerned with describing the effects of artwork through an intermediate space between the person and the actual work of art. 'Knowing' art, not its material alone, constitutes aesthetic experience. In this intermediate space, idea and emotion are stirred: aspects of art are felt and known. Dewey distinguished the spiritual and the ideal (Dewey 1980) from the material. The quality of material objects is felt and known spiritually in the margins between inner and outer reality. Experiencing takes place in the relation between a person and their environment.

Dewey explored the relationship we have with our environment (using aesthetic experience as a model). He noted the following elements of interrelationship and separation that are necessary for mature thought to emerge and for learning to become transformationali.e., as new concepts form from old ones. He pointed to the rhythm of loss and recovery that is essential to enjoying harmony with life experience. We become conscious of ourselves, our concepts and the world through the rhythm of loss and recovery. Emotion is the conscious sign of a break (actual or impending) in our union with the world and our ideas about it. Discord caused by emotion is an occasion that induces reflection. A desire to make peace with the world converts mere emotion (e.g., fear) into interest in objects that may restore harmony between our understanding of the world and our sense of being authentically engaged with it (Dewey 1980).

For example, a child who is terrified of them may choose to do a class project on spiders. Somewhere in the depth of curiosity, fear dissolves. Inner harmony between the way we think the world is, and how it seemed to be moments before we were carried away by curiosity, returns when our sense of self, concepts and knowledge of outer reality are again happily related. Losing and recovering the world leads to transformational growth: with development, concepts in the margins between the material world and a child's personal world shift their shape. It is this same process of loss and recovery that Job demonstrated as he strove to understand God. The book of Job is a narrative that shows how God concepts shift and change as the light of God's actual being shines on human experience. By working out emotions inherent in loss and recovery, a child is organizing experience into a meaningful whole (a mental mythology) that seems to be in place by early adolescence. By this point, the young begin to use clues from the outside world to confirm or challenge the worldview they have been forming since infancy.

\section{4. 'Experiencing' God}

Rizzuto explains how the process of loss and recovery is necessary for the growth and maturity of God concepts. She identified four primary God concepts through her research. She studied patients as well as hospital personnel to arrive at her analysis, since she wanted to "extract from psychopathology what might be of benefit to normal psychology", as Freud also intended to do (Rizzuto 1979). The four God concepts include people who

- Have a God whose existence they do not doubt;

- Wonder whether to believe in a God they are not sure exists;

- Are amazed, angered, or quietly surprised to see others deeply invested in a God who does not interest them; 
- Struggle with a demanding, harsh God they would like to get rid of, if they were not convinced of this God's existence and power (Rizzuto 1979).

Religious educators are wise to listen and observe children to get a sense of God concepts already formed in a child's mental mythology based on object relations experience.

A powerful implication of Rizzuto's research for religious education is that all four God concepts cause people difficulty if there is no transformational learning. Her central thesis is that "God as a transitional representation needs to be recreated in each developmental crisis if it is to be found relevant for lasting belief" (Rizzuto 1979). Further, she notes that God concepts are linked to self-concepts. There is a dynamic, sometimes dangerous, link between self-concepts and God concepts, so that the task of teaching religion to children demands careful attention to the child's experience as teachers present formal religion to the young (Rizzuto 1979). A child's creation of a God concept is a private process taking place in silent exchanges with other people and objects in the world. These exchanges are not based on words per se. After infancy, educators and authority figures contribute to the shape of God concepts. It is not simply what people say, but what they are and do, that children use to reshape God concepts according to personal needs and daily experience (Rizzuto 1979).

For example, in the space between mother and child, generalized representations form from a host of experiences common to infancy. In this space, children play with reality, inner and outer and form transitional objects that constitute the mental mythology each of them lives by. A child's sense of self develops in relationship to the mother's sense of the child. If the child sees themself as wonderful and worthy in their mother's eyes, all is well, or at least, it is good enough for the child to flourish because the child can relax. However, if the image formed is of a bad child, if a child has not been able to fulfill parental expectations that arose before the child was born, a conflict of being develops. If children sense that what is wrong is not what they do, but what they are, and realize they cannot please parents or God with their current way of being, yet they wish people around them to be happy, they must become a different sort of person. A child in this situation can never relax (Rizzuto 1979).

A child's sense of self is affected by representational traits of personal, private God concepts so that God-as our own creation-is like a piece of art, a painting, or a melody, and reflects what we have done, seen and been; it continues to influence one's sense of self (Rizzuto 1979). Once created, God concepts, dormant or active, remain potentially available as representations for the continuous process of psychic integration. As such, they can be used during religious education because, to Rizzuto, God concepts are beyond magic in the sense that all transitional objects are never under magical control the way internal objects are, nor are they under manipulative control, the way outside objects are, for example, one's parents (Rizzuto 1979). However, if children have negative, frightening God concepts, an intervention from religious educators that takes no account of what is already in play in the child's mental mythology, can produce an effect that is more than children are able to bear (Rizzuto 1979), and signals a serious absence of spiritual care.

As children age, there are interrelationships among God concepts and self-concepts, such that crises in experience influence both. Throughout a child's formation, God concepts, the rhythm of loss and recovery, attachments to other people (particularly parents and close family members, e.g., grandparents) are all instructive to their spiritual growth.

\section{Conceiving God in Our Need for Others}

For children to receive the benefits of spiritual care, they need to be in consistent, loving relationships with caregivers who meet physical, emotional and psychological needs as well (Clinton 2020), particularly through a process called affect attunement, which is an intimate form of communication between adult and infant. The process of spiritual formation in the young rests on the human spirit's capacity as an agent of communication that builds meaning, specifically in the form of a worldview children have in place by early 
adolescence. A worldview is full of concepts children live by that shape their expectations of the world, themselves and other people.

Infants' subjective experience of the world is largely shaped by biology (e.g., Kagan 1998) and they are co-creators of what they experience. They use a form of communication that relies on making sounds and gestures, but especially relies on the eyes. Even little infants can initiate, sustain and terminate an encounter by using their eyes alone. Babies can look at their mother's face, turn their heads and look at an object in the room and get their mother's attention focused on that object with them. Then, their eyes can glaze over until the mother realizes the visit has come to an end. The relation between mother/child is (potentially) a rich experience of affect attunement (Stern 1985).

One aspect of gaze behaviour helps an infant form the most basic beliefs they hold about themselves, the world and God. Mirroring through gaze behaviour is the first step. In gaze behaviour, when a mother and infant interact, if a mother's face is unresponsive, the mirror (her face) is a thing to be looked at but not into. To create a healthy sense of God's identity, and a happy self-concept, the infant's gaze must pass through the mirror (a mother's face) to where the real mother dwells (Rizzuto 1979). The child needs to sense there is something more than a face to look at. Behind the face is a person who has an interior, a psychic reality that the child can look into; this complex experience grounds children's belief in their own personal interior. A foundational result of a positive experience with affect attunement is the formation of hope and trust in a child's heart. It is through attachment to others that self-concepts and God concepts develop.

There is a need to re-envision religious education to take advantage of these insights. As we attend to and observe infants, we get a better grip on the processes of attachment and can improve children's connection to God through experiences that help them reflect on their own God concepts in an environment that is conducive to thinking of God as loving, kind and willing to be in a personal relationship with them. Having a God concept is different than having a personal relationship with God. In her research, American psychologist Lisa Miller (2015) probed this spiritual/personal connection to God and provides insights that are outlined later in the article.

God concepts are personal constructions that form independently of formal religious instruction. They have a reality that persists in shaping the way children think about the world, other people and the self. As a result, a God concept has the power to act as an idol situated in the inner shrine of a human heart as a stronghold that is unmoved by formal religious education, unless educators understand how God concepts form in the first place. If we consider twentieth century Christian training, as one example, it was common for Sunday School teachers to accuse children of placing themselves on the heart's throne. Some readers may remember an image of an inner throne on which stubborn, selfish children placed themselves, instead of choosing to do the right thing, which was to place God on the heart's throne. That approach to a child's religiosity did not perceive how God concepts form. There are several assumptions in an approach that locates the will as the central focus for a child's religious instruction. The first is to assume that God is placed on the heart's throne by an independent, conscious, intentional choice and can be removed by another independent, conscious, intentional choice. A second assumption takes it for granted that God might not be there, hence the child must put God in God's place. A third assumption presupposes a uniform concept of God that applies to everyone and that is unproblematic. Adults may assume the God concepts they hold are the same as the child's concept. If adult God concepts cause their owners no trouble, it is unlikely to occur to them that a God concept could cause trouble for a child.

It is important to note, in contrast to focusing solely on a child's will, that the greatest concern for formal religious education is to help children sense the concept of God that is currently reigning in their hearts. Inadequate, hurtful, or inaccurate concepts of God are a more serious threat to spiritual formation than self-centeredness, though perhaps the two obstacles are related. A concept of God is inadequate or hurtful if it is incapable of sustaining a healthy response to life because it cannot address a child's actual experience 
and the theological questions children begin to ask at a very young age. Children need to have a broader view of God rather than relying on personal concepts only if God is to be an attractive attachment. Children must come to understand that religion is serious business (Pratt 1956), and that God is more than what they can easily imagine.

As an example, Rizzuto showed that even an apparently positive concept (e.g., God is good, kind, loving) may interfere with our capacity to mature in faith. For example, she analyzed the experience of people who domesticate God. To some, God is a homey, safe divinity of simple human attributes, lacking the powerful dimension of transcendence (Rizzuto 1979). The transcendent God, the God above our little concepts, is revealed through the normal crises of doubt and disbelief that accompany adolescence, and that inevitably requires self-examination, self-searching and self-revision. To get too comfortable with God is ignorance of God. The self-examination implied in spiritual crises draws a believer toward humility and grace, away from ignorance and arrogance. God must become a problem during adolescence before God is a solution to one's spiritual quest-and its destination in adulthood.

The significance of this point is central. It is not by casting oneself off the heart's throne that maturity begins. Rather, getting a fresh and enlivened vision of God's own self enables a child to grow up in faith. We perceive God's goodness through the kindness of others. Until we revise them through exposure to communal knowledge, self-examination, and through transcendent experience, our God concepts are illusions-which again, is not to say they are false; they are incomplete. The plausibility of God concepts must be addressed if we want children to grow up well.

Think for a moment of someone with whom you are in conflict. What is your thinking about that person like? Maybe you imagine that person humiliated in your presence, and you feel satisfied. Suppose you are conscious of an internal conversation you have with that person: he or she says one thing, you say another, and on the conversation goes. In the debate, you score all the points and the other is stupid, evil, or whatever you wish. Notice your internal conversation. While it seems real, and to that extent satisfying, it is an illusion. You invent yourself and the other-motives, words, admissions and all, which is not to say you have no access to data about the other, but rather that you control both the data and your interpretations based on them. The only way you can know another person is to have an actual conversation in which you let others speak for themselves. You need the other to know the other. All else is a product of personal invention.

This example illustrates what we must accomplish if we want God concepts to grow up. We must sense the narrative we currently tell ourselves about God and decide if this is the story we still want to tell. Rizzuto explains the dialogical nature of human minds by describing the entrance of a child into a social world that has already mythologized a child's meaning in advance of their birth (Rizzuto 1979). Parents have preconceived ideas about their infants, shaped by life experiences, including their own childhoods. These ideas hang together in a narrative that makes sense to the parent. The child enters that narrative and in the first few years of life constructs a God concept that must be reckoned with throughout life. Parents who are flexible and attentive to the young respond to their actual baby rather than to preconceived fantasies about them. Part of 'good enough' parenting is a willingness to hear one's own narrative about a child and listen to a child's self-story. Once again, spiritual care for the young begins by listening to them and observing them. In the same way, in the process of telling and retelling stories that populate a worldview, God must be allowed to speak for God's own self. However, first we must sense the role played by illusions in that mid-space between our personal experience and the world of other people.

Thinking is powerful. Letting God speak and be heard allows the young to perceive differences between their concept of God and God's own self. The internal/personal concept people hold for God is a post-modern equivalent of idolatry that, unless transformed, limits learning. Until we understand how concepts form, it is difficult to progress in establishing a healthy view of God or of the self. Again, God concepts are personal 
and private. If formal learning is to contribute to growth, wise teachers take account of personal, private concepts that constitute the bedrock of belief. Educators must find ways to authentically connect children with traditional, formal views, if religious education is to be effective in linking children to a faith community. Without spiritual care, learning does not produce the transformation that personal, private concepts must undergo if they are to sustain adults through the crises of ordinary life and lead them toward maturity.

God concepts are personal rather than accurate. They are based on experience. As a result, an education to help children chart their way toward happy self-concepts and healthy God concepts must allow children to name their current concepts and see what religious texts reveal, without humiliating a child, criticizing the concept that is already in place, or setting the child up for failure by letting a child speak and then pointing out how wrong they are or by focusing on what they missed. Children must see the differences for themselves, largely through encountering text themselves. A child examines what is held in the heart (the centre of human willing, thinking, feeling and acting) and compares/contrasts it with what is revealed in the faith tradition, under the condition that education is taking place in a supportive, loving community. The tradition has the capacity of a large theatre of experience; spiritual care helps children find their place in it.

In summary, the sections above focus on children as they form concepts of God. The ways a child is regarded, spoken to, gazed at, touched and held convey important information as the young imagine God. Children need to be with people who perceive God as friendly in order to see God positively and imagine that a personal relationship with God is a possibility for them. Learning about God is dialogical. The young need to sense how they conceive God and dialogue with their own concept, setting it beside tradition, communal experience and text. They need time and opportunity to express themselves, without ridicule or embarrassment. The human spirit is shy. It is only in a welcoming environment that children feel safe enough to say what they think, based on what they have come to believe. They need to have their questions answered and be challenged to think well about faith issues.

\section{Spiritual Experiences}

As mentioned, one purpose of this article is to describe spirituality broadly so that spiritual care can become the foundation for religious education. Spirituality is often linked to religion. There are three possible ways to connect spirituality and religion. The first possibility is to say that religion and spirituality are virtually the same and the two terms can be used interchangeably. A second possibility is to say that religion and spirituality are entirely different and have little or nothing to do with one another. A third possibility is to say that spirituality and religion are related but different, in that spirituality applies to everyone and religion concerns some people. Both terms imply a human capacity for experiencing transcendence. In definitions that coalesce under this third possibility, spirituality is often described with respect to world religions and atheistic or agnostic points of view, so that an experience of transcendence for the last two categories (atheistic, agnostic) might apply to an encounter with nature. The third option is the position taken in this article and most closely supports the view that every human being is spiritual.

Further, spirituality connects people to other people. Human spirituality is best understood as a sense of felt connection and the idea of connection appears in many of the ways spirituality is defined (Bellous and Clark 2022). As already mentioned, the human spirit gathers life experiences into a meaningful whole, which is not to suggest the meaning children make is without internal conflicts and contradictions. For one thing, the personal meaning system that is produced through experience begins at birth when infants are helpless and need others to act as meaning makers with them. It is often the helplessness, dependence and disappointment that result from our need for others, which must be addressed in God concepts that children form. Rizzuto suggests that this was the case for Freud. One aim of spiritual care is to offer children greater access to the meaning they have made personally, and at the same time, help them become effective in social interaction in 
a faith community, so their worldviews are not limited by what they think, imagine, feel and do all on their own.

Spirituality as a human capacity, based on a felt sense of connection to transitional objects, allows children to see how spiritual experiences inform daily life. There seems to be ample evidence that spiritual experiences inform daily life. One starting point is found in the work of British zoologist Alister Hardy (b.1896). He went to Oxford in 1914 and read Zoology under his tutor, Julian Huxley, who was the grandson of T.H. Huxley-the man who was "known as Darwin's Bulldog for his fierce defence [sic] of the theory of Natural Selection" (Hay 2007). Hardy studied under the strong influence of radical skepticism about religion and God's existence. That skepticism was referred to as mechanical materialism and was the proposed certainty that a human body is essentially a machine without a soul (Bellous 2015).

The reason Hardy's research matters to spiritual care is due to its roots in scientific investigations he initiated that continued over the last 60 years. His research ignited interest in spirituality. After he retired as professor of Zoology at Oxford, Hardy gave all his energy to investigating what he called religious experiences, which we now call spiritual experiences. As a result, he was certain that all human beings (members of the species Homo sapiens) have the potential for spiritual awareness (Hay 2007). He further argued that spirituality has a biological basis: the way the human body is formed, and how people become members of a social group, allows them to experience what cannot be seen, touched, tasted, heard or smelled, i.e., human beings are capable of transcendent experiences that go beyond what is available to the five senses.

In 1969, Alister Hardy founded the Religious Experience Research Unit (RERU) at Oxford University in Britain with the "purpose of making a scientific study of the nature, function and frequency of reports on religious experience in the human species". (Hay 2007) It is important to note that he did not speculate on God or God's existence but focused on human spirituality. British spirituality researcher David Hay continued Hardy's research and summarized data he gathered in 2000, which he compared with data gathered in 1989 by Hardy.

The comparisons Hay drew indicated a significant upsurge in people's reports of spiritual experiences in Britain between 1987 and 2000. It is noteworthy that, during this time period, while reports of spiritual experiences increased, church attendance declined. In his book, Something There, Hay notes that an increase in spiritual experiences and a decline in church attendance was evident across Western Europe.

Hay did not speculate on that inverse relationship but provided a useful description of spiritual experiences. Instances of spiritual experiences include the following qualities:

- A patterning of events that persuade people the events were meant to happen due to a transcendent providence;

- Awareness of the presence of God;

- Awareness of prayer being answered;

- Awareness of a sacred presence in nature;

- Awareness of the presence of the dead;

- Awareness of an evil presence (Hay 2007).

Hay gives specific examples of these experiences as recounted by those who offered them to researchers. In his summary, he provides spiritual care with vital and valuable approaches to understanding experience, for at least two reasons: there is evidence that spiritual awareness is universal — everyone is spiritual —and that spiritual awareness comprises the qualities Hay identifies. Attentiveness to his research is foundational as we listen to and observe children and youth.

However, an important element of Hay's research does not fit well with educating the young. For the most part, spiritual experiences in Hay's list are personal, not social. They are experiences one can have all by oneself and therefore pose an educational problem for children. Children's development is relational; they need other people. There are spiritual needs that lie at the core of spiritual care. These needs include the following: 
Every human being has a spiritual need to celebrate, mark significant moments, bear witness to truths learned about life, play, tell their story, pray, grieve, mourn, lament, connect with the past, make significant journeys, express themselves symbolically, seek purpose and meaning, ask ultimate questions, have a satisfactory way to think and speak about the beginning and the end of life, survive, flourish, experience longing and enjoy its satisfaction, relax, cope with life circumstances, be seen, be heard, have a name that's remembered, be part of a larger community, organize experience meaningfully so as to make sense of it, maintain human dignity, see the future as hopeful. (Bellous and Clark 2022)

Meeting these spiritual needs provides significant benefits to human groups.

In summary, Hardy believed that "certain forerunners of Homo sapiens 'consciously chose' to attend to the spiritual dimension of their awareness", with the result that they received its benefits in terms of the "strength to cope with the dangers and difficulties of their physical and emotional environment" (Hay 2007). This positive view of spirituality's effects has continued to gain strength. As one example, American psychologist Lisa Miller made use of a 1997 study that was a landmark scientific article published in the American Journal of Psychiatry (Miller 2015). Its research provides evidence of hugely beneficial dimensions of spirituality. Its conclusions are empirically derived. That study uncovered the significance of "a personal relationship with the transcendent" and argued that the relationship makes crucial and valuable contributions to "good health, mental well-being, fulfillment and success" (Miller 2015).

Miller goes further than saying spirituality is a human capacity, spirituality is more than religion, and everyone is spiritual. In The Spiritual Child she argues, using scientific data, that spirituality is "an inner sense of living relationship to a higher power (God, nature, spirit, universe, the creator, or whatever your word is for the ultimate loving, guiding life-force)" (Miller 2015). In making this assertion, she implies that spirituality involves two parties: there is someone who has a capacity for felt connection with the Unseen and there is Something There that acts back through that connection to provide relational meaning and support.

A central aspect of Miller's view is that a relationship with the transcendent must be personal and personally sought, secured, and lived out in the daily exercise of one's values and behaviour because that connection builds what she calls an inner spiritual compass. In her view, this compass is an innate, concrete faculty. Like emotional intelligence, it is part of our biological endowment. She asserts that it can be educated. She notes that her evidence for an inner compass is "hard, indisputable, and rigorously scientific" (Miller 2015). She cites a twins study carried out by Kenneth Kendler that asked about the relationship between spirituality and religion. He concluded that, in his research with nearly 2000 adult twins, "in people's lived experience, personal spirituality is a different concept from adherence to religion or choice of religious denomination", and Miller notes that, in Kendler's research, "spirituality did not meaningfully correlate with one specific religious [group because] there are highly spiritual people who [do not] adhere to any specific religious [group]" (Miller 2015).

Miller provides a caveat when it comes to the relationship between spirituality and religion. She notes empirical research that methodologically identified what is not meant by her term personal spirituality. In her data, spirituality is unrelated statistically to strict adherence to a religion or a creed if there is no sense of personal choice or ownership. In other words, healthy spirituality is personal. One function of spiritual care is to listen for the ways that personal choice and ownership are given voice as we engage with children. In the spiritual care offered to children, the relationship is central to healthy development. Helping children reflect on the worldview they have been forming through life experiences is the centerpiece of an educator's effort to build religious learning on a foundation of spiritual care. 


\section{Forming a Worldview}

Up to now the discussion of spiritual care involved exploring spirituality and the ways children form God concepts and the idea that God concepts and self-concepts are intertwined within worldviews that form from infancy. As mentioned, human beings form a worldview that acts back on the way they experience life. In order to explicate four types of literacy or reading strategies (cognitive, emotional, imaginative and social) at the core of spiritual care, this section situates them in a discussion of the brain's involvement in thinking itself from infancy onward. The acquisition of a literate stance with respect to cognition, emotion, imagination and social engagement is based on human capacities we all have as we acquire experience and make meaning about life, the world and our place in it. If human spirituality is understood as a felt sense of connection (Bellous 2015), the vitality and strength of the four reading strategies depend on spiritual work children practice as they reflect intentionally on life experience. Their spiritual work is to make meaning that, over a lifetime, shifts and changes based on intentional reflection.

If spirituality is a felt sense of connection, that felt sense is rooted in infancy (Klein 1987). At birth, an infant is a stream of sensations that eventually organizes into patterns that become concepts to use when thinking, feeling, investigating and deciding. These concepts show up in one's worldview. Sensory percepts (sense data) streaming into an infant brain (cortex) create cortical effects that gradually work into shapes and patterns: some of the effects form the concept 'me' and some form the concept 'not me' (Klein 1987).

British psychologist Josephine Klein (1987) composed a picture to help us understand how we come to identify as ourselves and form our picture of the world. The way she explained it, identity slowly forms to include aspects that create the situation we find ourselves in as we interact with others. At the beginning, if conditions are favorable, infants fuse with their mothers and do not distinguish themselves from them. Over time, an infant emerges into a self. The term e-merge refers to coming out of this merged connection between mother and baby. As Klein put it, "somehow the baby has to e-mergecome out of the merge. As babies e-merge, so do (m)others" (Klein 1987). If all goes well, a baby becomes aware of itself as distinct from its mother, as evidenced when they 'make strange' with other people. Emerging is a foundational experience for comprehending all other objects in the world, including other people.

At first, the child is this stream of sensations, or the stream is the child. The mother acts as skin might do, before the infant has developed what one might call its own skinsomething to contain all its fluctuating sensations (Klein 1987). If all goes well, the mother acts as a container, a primary nurturing containment for the child's stream of sensations until the child becomes aware of its own skin. If she is able, the mother holds the child until the flow of input is steady for long enough to allow "pattern-making ... pattern recognition, some organization and structuring, to take place" (Klein 1987). The mother helps put things in perspective, so to speak. If all is well, this process takes place between mother and child (Stern 1985, 2004); both mother and infant are active agents within and during it (Stern 2004).

Worldviews form from infancy based on conceptual learning. A stream of sensations entering the infant brain activates nerve cells. As a result, nerve cells (neurons) converse with one another. They send electrical impulses to one another so that one nerve cell excites another. These messages continue to move from neuron to neuron among networks of nerve cells (Hebb 1980) to form a communication system within the human body. As sensations enter the brain, they excite some nerve cells that are linked to the external world through a child's organs (e.g., eyes, ears) and to various parts of the body, for example, when bones or muscles change position (Klein 1987). This brain activity is the basis for a child's ideas about the world. The process is a source of learning and establishes memories and constantly provides infants with the knowledge (Hebb 1980) they accumulate in a developing worldview.

A second set of nerve cells is linked to each other and not to the external world. It is this second set that is responsible for concept formation, e.g., mother, father, God (Rizzuto 
1979), sister, brother, women, men, to name some concepts that populate a worldview. In forming a worldview, concepts do not erase percepts. We have ongoing access to concepts and percepts; while percepts are sense-based, concepts are not, in a strict sense. In this process, thinking is distinguished from sensing, but is also related to it. Canadian psychologist Donald Hebb provided a framework for how the brain thinks (Hebb 1980).

The typical human being has a complexity of about one billion cell assemblies. This complexity is what makes the normal development of intelligence and learning possible, including a capacity for abstraction and generalization (seeing patterns) that is fundamental to human thought (Hebb 1980). As mentioned, a percept consists of cell assemblies excited by the senses; a concept forms by assemblies that are excited centrally in the brain by other assemblies, i.e., by their own internal communicative interaction (Hebb 1980). As far as thought is concerned, the development of new concepts is a process of modification in the ongoing development of old concepts (Hebb 1980). All learning depends on this relationship between percepts and concepts.

When we talk about forming a worldview, we can ask about its content. Much of what is in a worldview is representational of the world; it is inherited. A worldview is based on a mental system, as Austrian-British economist F.A. Hayek pointed out in his research on theoretical psychology. Worldviews are shaped by conditions prevailing in our environment and represent a kind of generic reproduction of relations among elements of this environment that we have experienced in the past; we interpret any new event in the environment based on that experience (Hayek [1952] 1976). It may be said that meaning making flows from interactions among these two sets of neurons-one is externally linked, the other operates as an internal communicative system that organizes meaning.

This second set of neurons forms concepts without relying on direct sensory input (Klein 1987) necessarily. It is communication among these neurons that makes conceptual learning possible. For example, let us consider what happens before a child comes up with the concept 'triangle'. As percepts enter the cortex, the child sees an angle. The roundness and movement of the child's eye make it possible to see other angles: a child looks at one angle of a triangle and then looks for others so that a triangle takes shape. As the process happens repeatedly, the child acquires the concept 'triangle', which is more than the sum of three angles-it is a new concept (Figure 1). Children can then recognize triangles, sometimes as soon as they see only one of the three angles (Klein 1987). These kinds of abstractions (a triangle) cannot be perceived by the senses; they are conceived by central processes in the brain (Klein 1987).

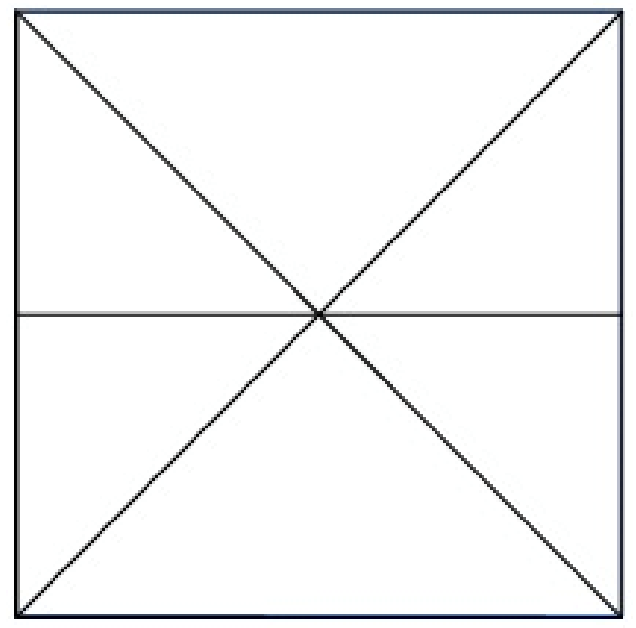

Figure 1. Count the triangles.

Two essential aspects of learning are active in the brain: perceptual learning (sensations linked to the external world and the body) and conceptual learning (stimuli that activate internally linked neurons that organize meaning). Conceptual learning works 
with perceptual experience-so that new learning may be independent of direct sensory stimulation and is expressive of the mental system to which Hayek referred. As some examples of his point, an association might have been set up by vision, and yet be manifest later by hearing a sound, a feeling or a touch; a child can be triggered by a tone of voice or facial expression from past experiences.

This classifying, conceptualizing process is the meaning-making labor everyone necessarily carries out. As mentioned, creating meaning is personal, spiritual work because the work includes God concepts and is distinguished from purely existential meaning making. Psychologically, it is viewed as object-relations work insofar as it is the unifying activity that produces meaning by considering objects we encounter in life, including God.

Returning to Klein's picture, she suggests that the process of thinking must be something like this: a sequence of events starts when central neural activity is a stimulus for communicating with other neurons, without needing the intervention of a sensory stimulus (Klein 1987). She notes a difference "between fleeting and more enduring changes in the nervous system, making it possible for more central dominance to emerge (Klein 1987). Establishing more central neural control is a victory of a person over an environment, enabling a child not only to adapt to their environment, but eventually to have agency within it. This is part of what happens as we e-merge, mentioned earlier. As we are thinking, we draw on memories to evaluate current events that provide the benefit of past experiences. However, children are not aware of all that it is possible to see. It is the role of spiritual care to help children extend their horizons. As an example, look at the square diagram. How many triangles do you see? Klein includes the diagram in her book and notes that she found fourteen triangles in this square.

As mentioned, the classifying process that shapes a worldview begins in infancy. The image of the homunculus conveys where an infant's body initially records data. A baby begins to collect and organize percepts that form their foundational picture of the world. We have all seen how babies put everything in their mouths as they explore, hence the relatively large mouth in the image. The homunculus (Figure 2) is a depiction of the sites where percepts gather; note the large thumbs. In this way, a human being is a place where things happen; then children become a self-recognizing object, and eventually, agents of their own experience. This meaning making growth is both a perceptual and conceptual process. Based on the experience accumulating on the homunculus, a network of these connections reproduces a multi-sensory, complete record of everything that happens to a person from birth. This memory bank is called an Engram; a storehouse of all that comprises a person's complex, multi-sensory memories (Penfield 1975).

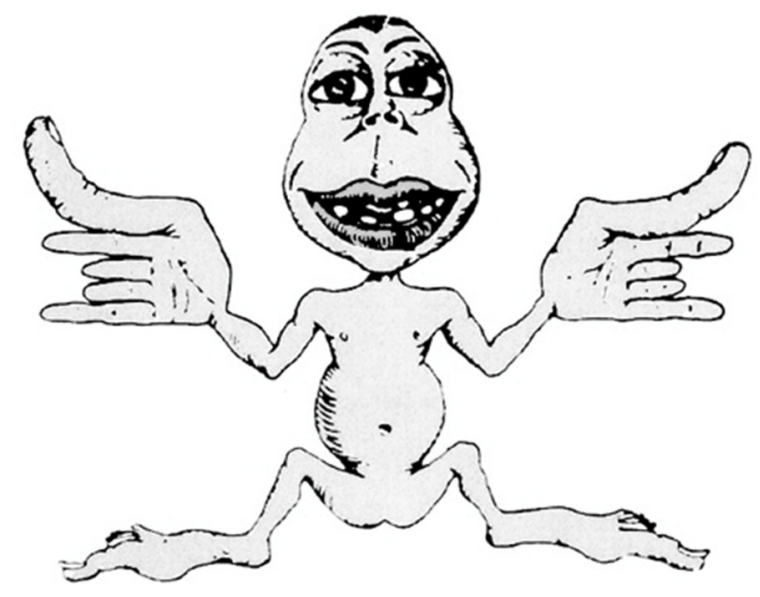

Figure 2. Homunculus.

In order to situate the meaning-making work human beings do, and connect it with forming a worldview, consider the idea of a felt sense. Klein's term, a felt self (Klein 1987), is the basis of self-consciousness that forms over time. American philosopher Eugene Gendlin 
describes the innermost experience of a child that eventually develops the complexity of a felt sense, which is a stream of sensations (consciousness) organized into concepts and classified into patterns. Within a felt sense, one is potentially aware of elements of one's stream of consciousness in a studied, accessible, attentive manner (Gendlin 1962).

In terms of conceptual learning, there are two aspects of a worldview called a map and a model (Hayek [1952] 1976). A map slowly forms which consists of concepts and connections between these concepts, referred to above as the Engram. The map is not twodimensional; it is multi-dimensional. It defines the relationship of everything to everything else. We can think of many maps within this map, just as we would think of a map of North America as composed of many smaller maps: Edmonton, Vancouver, New York, Chicago, small towns, villages, neighborhoods, someone's living room or someone's bedroom. A mental map has that sort of complexity and depth.

However, at birth, there is no map-only the homunculus. Infants cannot organize their picture of the world in an adult fashion because not enough has happened to get more than a blurry sense of what is going on (Klein 1987). As learning accumulates, based on inherited and personal experience, an internal meaning system will contain three elements: a sense of self, a sense of other people and things, and a sense of what goes on between the two (Klein 1987).

The second aspect of a worldview is the model, which is a representation of a given moment. The map and model each contain a self-concept. The model is experienced within the map; the map is its background. A child begins to adjust to elements of a given moment that are active during social interaction. The map has its full effect on how a given moment is read by the child. Suppose something happens; an event occurs, e.g., one child takes away another child's toy at a daycare centre. The child whose toy is taken away will respond based on map and model congruence. The child may have learned to share, or the child may constantly have toys taken away at home. In the second case, the child may have come to believe: "I am someone who does not get to keep the toys I want". A child tests incoming experience against the map and their developed sense of whether the model is like or unlike the map. The map is the 'familiar' against which the model is scrutinized. Next, the child can judge whether an event resonates with how things should or should not be. The map is the standard into which the model must fit.

If an event is congruous with the map, the child can let it go. It is simply the way things should be. However, if an event is unlike the map, the child may sense something should be done about the mismatch. A process of testing and finding congruity or incongruity is carried out until a given moment is like the map. Each worldview map is constructed from experiences that are unavailable to other people, even those who are close. Consequently, as we encounter children, we have no sense of the whole map that stands behind a given moment for them. We gain no access to that map except by asking about aspects of it. If children experience dissonance between map and model, they may react with what looks like defensiveness or anger. It might not be defensiveness or anger, but rather, an urge to correct the model so it fits the map. In a mismatch, children can easily feel they have been misunderstood. At this point, a child's skill with self-regulation is of utmost importance in how they address a mismatch (Clinton 2020).

As experience accumulates, it is somewhat fluid; but over time the map reifies. As it develops into a system of interlinking concepts, a new event is less likely to affect its overall organization. In general, worldviews are established by early adolescence. The map is an internal organization based on past and semi-permanent connections composed of memories that create a personal meaning system that suggests what the future will hold. Any new event encounters the whole construction and can only modify behaviour in the light of the whole picture. The map is a relatively enduring structure that describes the self. A given model moment also conveys something about the self. Map and model selves interrelate during every social interaction. Suppose a well-loved child experiences ill treatment at school by her teacher. The child can feel as if the map and model selves have split her into two parts. Under favorable conditions, map and model selves are closely 
linked, giving a sense of continuity, identity, direction and value (Klein 1987). However, that linkage can work in two ways. Unfortunately, it also allows a child who is mistreated at home to expect mistreatment in public.

Over time, the process of worldview formation results in embodied learning, as the example of eye movement and triangle conceptualization highlight (Klein 1987). Learning happens slowly and is ongoing. Its slowness is due to the complexity of which human thinking is capable. Perceptual and conceptual learning act together at times, and differently at other times. In addition, learning involves deciding. Human beings have a greater ability to steer behaviour in a particular direction than other animals, based on what they are learning (Klein 1987). An ability to steer behaviour depends on where we place our attention. As a worldview develops, neural structures come into being that involve an expectation of what will happen next and an impulse to do the next thing. One consequence of such structures is to make it possible for us to expect events to happen that have not happened yet. These expectations give meaning to events, so much so, that an expectation can seem to be the same as its actuality. As a result, children may confuse their expectations with what they believe will happen. Guiding children into the four reading strategies (described later) operates to help challenge and rethink expectations based on the precepts and concepts that are already housed in their worldviews.

All reflection is built on remaining awake to percepts that influence concepts. This is a cognitive/emotional/imaginative/social task children take on as they move from being a place where things happen to becoming agents of their own experience. Learning based on neural activity is foundational to becoming an agent of one's own experience. Spiritual care aims at helping children become agents of their own experience without becoming isolated in their own experience. This balance must be learned.

Slowly, children develop a multi-dimensional understanding of the world, other people and themselves. This understanding comes through the process of classification that eventually produces the patterns children hold in their worldviews. Classifications of concepts occur in the brain because the same entering event has the same effect whenever it occurs (Klein 1987), e.g., seeing the angle of a triangle. Concepts are the means for developing insight. However, children are typically unaware of all that is available to be perceived in a situation, as the square of triangles shows. Data are there to be seen, but are not necessarily perceived, even though there is no repression of what is going on. The young need guidance in order to see the big picture. Look at the following diagram. What is the error in each triangle (Figure 3)?
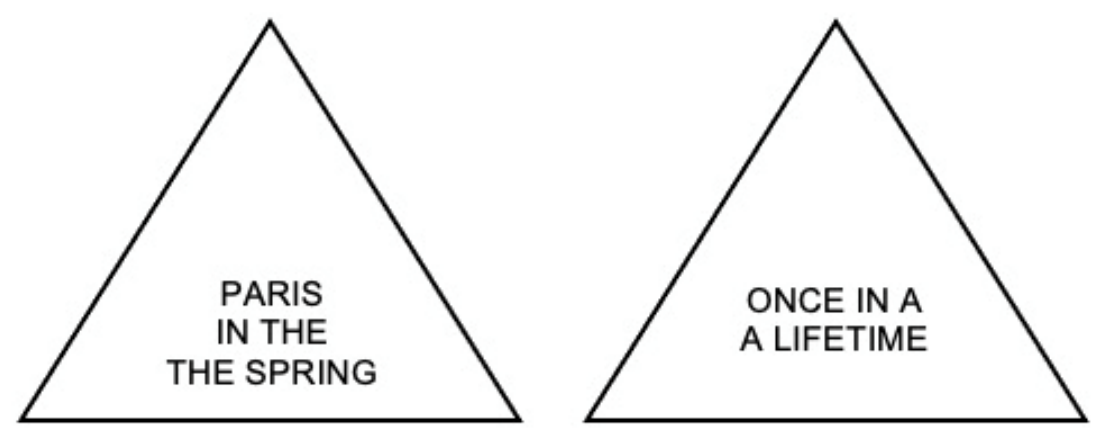

Figure 3. Perceiving Data.

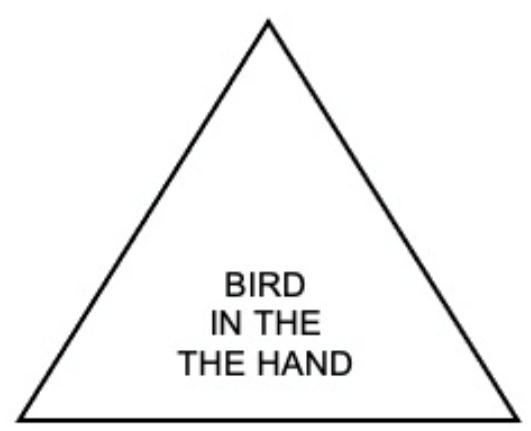

Children easily miss data that is present and there to see. For a child, a learning environment can offer opportunities to stop, think, listen, look at and look for what the child has not yet perceived. The four types of literacy are means by which children learn to reflect on their experience from a fully orbed perspective. Spiritual care plays a pivotal role as a child's worldview opens during learning so that new, healthy possibilities show up to the child. The four types of literacy (cognitive, emotional, imaginative and social) provide a child with a larger picture of the world than the one they currently hold. 
As adults listen to and observe children, and engage conversationally with them, they initiate the young into brainstorming options that provide balance for worldviews formed on personal experience alone. In spiritual care, the first move is to listen to the child and realize what they need next. Hearing the child is the first step in teaching them.

Hearing oneself in the company of others who listen, is central to a child's well-being. American literary critic Harold Bloom (1930-2019) taught Shakespeare for decades and summarized the bard's contribution to the development of personality:

Literary character before Shakespeare is relatively unchanging. Women and men are represented as dying and aging, but not changing because their relationship to themselves has changed. Shakespeare's characters develop because they reconceive themselves ... which sometimes comes about because they overhear themselves talking, whether to themselves or to others. (Bloom 1998)

The content of mental life is more than merely personal-we hear more than ourselves as we listen to what we are saying. As Klein put it, we do not begin life as individuals. We begin in relationship; "relationships are at least as basic as individuals" (Klein 1987).

Children acquire God concepts and inherited content throughout childhood. In the process of growing up, an adolescent's religious education needs to satisfy spiritual needs and offer opportunities to be self-aware and, over time, become agents of their own experience. Spiritual care is a relational resource within faith communities in which adults engage with capacities of the human mind, encourage children to be consciously aware of aspects of their worldviews and help the young consider whether ways they have been thinking and acting are ways they want to continue to think and act. As adults care spiritually for children and youth, they do so by paying attention to the meaning the young make of life, so that they can comprehend how their youthful social world is impacting them (Shrier 2020; Soh 2020). Spiritual care directs the young to look at and to look for data in situations, to bring their expectations to conscious awareness and brainstorm possible plans that might conform most happily with the kind of people they want to become.

Conscious awareness of one's own thinking is the heart of spiritual work. Harvard professor Robert Kegan points out that every one of us grows up with what he calls an orthodox faith. We get it in our family of origin. What matters, in educating a worldview from the perspective of religious education, is to realize that family religions are not synonymous with faith traditions. A family religion is one that operates powerfully and mysteriously in every family and is passed on to children by their simply being there. It may carry the name of a religion but is nourished by private rituals and customs enacted in that dwelling. It is a composite of deep, idiosyncratic beliefs and practices (Kegan 1994).

To Kegan, everyone has a family religion that forms inherited content in their worldviews. It is God concepts and inherited content that religious education in the twenty-first century needs to address, along with providing a large, rich picture of a faith tradition. Religious education must stop seeing children as empty vessels to be filled. Those who understand spiritual care as the foundation for religious teaching invite the young into conversations that invite personal concepts into a living community of thought and practice, so the young become fully fledged, thoughtful, reflective practitioners of it.

\section{Four Types of Literacy in a Competent Spiritual Care Context}

Up to this point, the genesis of God concepts, spirituality research and the formation of a child's worldview have held center stage in an explanation of spiritual care. Insights about spirituality based on research indicate that its current findings would not fully meet a child's spiritual needs. Children need other people. While they may share some of the spiritual experiences noted earlier, to suppose children by themselves can realize the full potential of the human spirit is misguided, if not a form of neglect. Children need a learning environment in which they are accompanied by competent adults who are deeply interested in them, in what they think and say, imagine and do, and in what they need.

The four types of literacy outlined in the next section comprise a teaching/learning approach that meets the spiritual needs of children and allows them to express, not only 
their thoughts, but their way of conveying what they really care about, including how they try to improve a situation and make the world a better place. The four types are based on adult and children's Spiritual Styles Assessments (Bellous et al. 2009a, 2009b). While the Assessment identifies personal style, spiritual care expands on the Styles by showing how each one develops into a competent reading strategy with respect to cognitive, emotional, imaginative and social competencies.

A competency is an ability that relies on underlying attributes of a person's character. In the process of learning, these attributes (characteristics) are either already present or are learned through practice until they become durable and enduring. As a result, people can be counted on to demonstrate them behaviourally. A competency expresses specific values that are described along with characteristics that include more than knowledge and skills. There are attitudes associated with competency.

Some aspects of competency are visible in action and can be observed by others; some are not so easily observed in outward behaviour. When assessed, competencies predict who will perform well and who will perform poorly (Spencer and Spencer 1993). The words competency and competence are related in that the first term describes underlying characteristics of, for example, cognitive literacy. The second term, competence, refers to a person's degree of accomplishment as compared with ideal performance of characteristics, attitudes and skills inherent in cognitive literacy. Competencies associated with the Styles comprise a complex, interwoven ability set that includes six dimensions:

- Motives: what a person constantly thinks about and what causes action;

- Traits: physical characteristics and consistent responses;

- Self-concept (1): a picture one has of oneself and the value one places on it;

- Self-concept (2): congruity or incongruity between map and model;

- Knowledge: data accrued re: cognitive, emotional, imaginative and social tasks;

- Skill: the ability to perform mental, emotional, physical and spiritual tasks (Spencer and Spencer 1993).

Sections that follow describe the four types of literacy and rely on a child's capacity for developing literacy in these four areas if they are welcomed into religious communities in which competent adults pay attention to children and share their own competencies with the young.

\section{Emotional Literacy and Social Literacy as Developing Competencies}

In a workbook used by the Korn Ferry Hay Korn Ferry Hay Group (2011) to assess emotional and social intelligence, the core terms describe competent adults in the following way:

Emotional and social intelligence is the capacity for recognizing our own feelings and those of others, for motivating ourselves, and for managing emotions effectively in ourselves and in others. It describes behaviours that sustain people in challenging roles, or as their careers become more demanding, and captures the qualities that help people deal effectively with change.

This view of emotional and social intelligence is built on American psychologist and science journalist Dan Goleman's two books, Emotional Intelligence (Goleman 1995) and Social Intelligence (Goleman 2006). Together with American psychologist Richard E. Boyatzis (an expert on emotional intelligence) they worked with the Hay Group to develop an assessment known as the Emotional and Social Competency Inventory (ESCI). The ESCI assessment highlights four areas of ability:

- Self-Awareness: recognizing and understanding our own emotions;

- Social-Awareness: recognizing and understanding the emotions of others;

- Self-regulation (self-management): effectively managing our own emotions;

- Relationship-Management: applying emotional understanding to social interaction.

Emotional literacy as a reading strategy develops on the strength of emotional intelligence, which is a capacity human beings have from birth. Recall that infants engage with 
parents in affect attunement and do so due to emotional intelligence that deepens over time. While emotional intelligence is primarily about self-awareness and self-regulation, social intelligence reveals that in every interaction, we have effects on others, and they have effects on us. From this perspective, we engage in an intimate brain-to-brain connection whenever we are with other people, for example, through gaze behaviour. Again, research on affect attunement supports this brain-to-brain interaction during infancy, as children collect percepts and develop concepts about the world.

During social interaction, the more strongly connected we are, the greater the mutual effect our interactions have on all involved. During an interaction, our brains engage in a dance of feelings. Feelings are contagious: they ripple through our bodies and send out a cascade of hormones that regulate biological systems from our hearts to our immune systems. Every interaction has an emotional subtext, with the result that relationships we find nourishing have beneficial impacts on health; toxic relationships can act like a slow poison in our bodies.

As a science journalist, Goleman summarized extensive research on human interaction to say that social intelligence is the ordinary capacity people have that allows us to be in a relationship with one another. To him, one of the core values of human interaction is caring about other people's needs in addition to our own. Goleman is very clear: social intelligence always includes concern for others. Without concern for other people's wellbeing, social intelligence would allow us to manipulate and bully others. Human beings are designed to connect. Children learn from their environment what to expect through those connections. People choose how to use these connections and steer their behaviour in a chosen direction, whether it is a healthy choice, or not.

Along with emotional intelligence, social intelligence is a range of capacities from instantaneously sensing another's inner state, to understanding someone else's feelings and thoughts. It is an ability to comprehend complex social situations and act appropriately while they are taking place. Socially literate people can think on their feet. Being literate during social interaction implies that our ability to read ourselves and other people (during the interaction) is smooth. Literate people use social intelligence ground rules in a skilled manner. Using social intelligence like an expert reader, allows a socially literate person to negotiate interactions, repair misdirections as they arise, and remain engaged with others. Ground rules for social literacy include having a developed ability to:

- Attend to another person;

- Pace an interaction;

- Engage in conversation;

- Tune in to another's feelings;

- Manage one's own feelings during the encounter.

In spiritual care, emotional and social intelligence act together to achieve satisfying social engagement. The outcome of their union is an artful ability to be true to oneself (to be authentic) while in the presence of people who matter to us, but who may differ from us. Emotional and social types of literacy form two aspects of spiritual care children require to live peacefully with the diversity that characterizes most human encounters.

\section{Cognitive Literacy and Imaginative Literacy as Developing Competencies}

In addition to social and emotional literacy, the use of reason and imagination ground two more competencies, or types of literacy, the young require to be intellectually healthy and well situated socially. As outlined already, human beings have the capacity to be active agents in the process of making meaning. As sensations enter the brain, they excite a network of nerve cells, some of which are linked to the external world through body organs to form percepts based on real objects in the world. Some nerve cells are linked to other nerve cells and their communication forms concepts, e.g., a triangle.

The capacity for using reason and imagination is grounded in brain activity. As adults educate a child's faith, reason and imagination function as organizing principles for gathering meaning into patterns, along with specific cognitive skills, for example, 
asking prior questions. In terms of brain activity, percepts and concepts produce thoughts, ideas and images. Conceptual learning works with perceptual learning in that conceptual learning remains open to perceptual learning (based on sense experience), so that children can acquire new thoughts and alter those previously held. All learning moves through this type of loss and recovery. As one example, a child leaves a teddy bear on the shelf, which up to that point, signified comfort and companionship, and runs outside to play with other children, who now constitute comfort (at least potentially) and companionship. In making this move, the child shifts attention from a teddy bear to children out of doors and learns to pay attention to what it is like to play with them.

Paying attention is a central reinforcement for human thinking. In addition, human beings are organizing organisms and what we organize is meaning, (Kegan 1982) as is evident from the way the brain works. Reason and imagination help organize meaning. While reason and imagination often work together, imagining refers to forming a mental concept or image of what is not actually present to the senses but that produces ideas and images. Imagining always has a quality of something that has not happened yet. The outcome of imagination and the means by which one imagines are usually linked to creativity. Imagination plays with pictures, thoughts, opinions, objects in the world and objects not available to the senses, inventing or recomposing until something new emerges. There is a sense with imagination that one is going beyond the ordinary world to form new or composite ideas, worlds, opinions, or practices that are not known with certainty. One can think of flights of fancy when the topic of imagination comes up. In existential contexts (as opposed to neurotic or psychotic ones), people know when they are imagining and when they are using reason, just as they distinguish dreaming from being awake.

Reason helps to organize meaning. Let us use the following definition: reason refers to a peculiarly stubborn effort to get clear about something (Gottlieb 2016). During its progress, reason generally produces statements, facts, arguments, either in written or spoken form. German social theorist Hannah Arendt (Arendt 1978) proposed that thinking is always about the past; reason uses what is already available through percepts and concepts and works with that material, sometimes relying on patterns or models, while imagination moves into the future.

Reason has to do with using selected ideas that ground or lead to a conclusion. The result may be an idea or an action. Reason relies on evidence, whether it is empirical (e.g., the accuracy of counting chairs in a room), conventional (e.g., definitions that rely on the way we tend to understand a word) or theoretical (e.g., arguments that are cogent because they match the way the world is, or are internally consistent, i.e., the ideas hang together). As we use reason, we may argue or discuss, but if what we write or say is reasonable, it comes across in a connected and sensible manner so that conclusions follow from points we make along the way to support those conclusions. As a result, other reasonable people can follow us to those conclusions, whether they agree with them or not. Socratic conversation and Aristotelian deliberation are some of the patterned approaches that can structure well-reasoned positions and points of view. If the point of imagination is creativity, the point of reason is clarity and making sound judgments.

Given the earlier discussion of brain activity, it is compelling to consider how Immanuel Kant (1724-1804) conceived of imagination. In his view, without the benefit of research into the brain, he positioned imagination as the mid-point between the activity of receiving percepts and forming concepts, so that imagination works with percepts and concepts. Aristotle (1980) also distinguished imagination from perceiving and conceptualizing by saying that, imagination is "different from either perceiving (aesthesis) or discursive thinking (noesis) though it is not found without sensation, nor is judgment found without it" (Caygill 1995). For these philosophers, imagination functions with perceiving and conceiving (though differs from both) and imagination plays out in making judgments as well. Based on this view of imagination, we might reasonably say that children have a spiritual need to look forward to a hopeful future and find their place in it. The fulfillment of that need depends on helping them effectively read situations in the fullest sense by pro- 
viding them with rich patterns for healthy reasoning and imagining. Despite the dissident reaction against Grand Narratives in the last century (largely as a reaction to the horror of the Holocaust), the implicit assumption here is that children function best when they come into a context that is a grand narrative that has the capacity to explain all of life to them (Bayard and Bellous 1999).

Perhaps an analogy will suffice. In teaching English as a Second Language to immigrant children entering Canada, one can observe a tendency that migrant families have of withholding from their children their fully orbed mother tongue and the worldview that supports it. Research showed, however, that the best predictor of success in learning a second language is a rich experience of one's first whole world. In his Prison Notebooks, Antonio Gramsci (Gramsci 2011) makes a similar point about the use of Latin in Italian education. He points out that, since Latin is a dead language, but is a whole rich world with intricate parts and explanations, children establish their own mental architecture on its foundation, so that each child possesses a whole mental world they understand, build upon, alter and develop based on their future learning.

Both examples stress the point that children require a foundation for thinking, imagining, feeling, and acting - which is not to say this foundation is the only one they will ever have-but rather than a child's mind needs its architectural groundwork in order to move forward intelligently and well. Kant makes a similar point about childhood learning when he posits that learning should establish memory and build reason on its foundation (Bellous 2015). Based on this insistence, caring for the human spirit in the young requires adults to give full attention to their cognitive, emotional, imaginative and social development. The next section provides four Spiritual Style scenarios, and educational approaches based on them, in order to explicate adult responsibility as the primary way of situating the young in a world they are then free to own and explore.

\section{Four Types of Literacy: Cognitive, Emotional, Imaginative and Social}

The following scenarios and explanations constitute the centerpiece of spiritual care for the young, as the foundation for their religious learning, although there is no intention to create an exhaustive list of the requisite skills in each style.

In reflecting on human spirituality, on children's spiritual needs and the formation of their God concepts, by understanding how conceptual learning works in the brain, educators can see that spiritual care allows children to grow up into a faith tradition eventually. One further note: when reading about the four Styles, it is essential to not apply gender stereotypes to them.

\section{Word Style Scenario}

Nora's friends do not understand why she would rather talk about ideas than go to the movies. She is part of The Debate Club at school and loves to hear the two sides arguing over the meaning of a word. She loves to win the argument. Much of her time is spent with her nose in a book. She loves to know the precise meaning of things. She was angry in science class the other day when she asked about the meaning of a word her teacher was using. She thought the teacher's answer was inadequate because it left out a lot. Nora loves to defend her ideas at dinner. She corrects her brother, sister and her parents if they're not being clear. Nora's dad gets frustrated because she needs a detailed explanation of why something must be done rather than just doing what she is been asked. When she makes decisions, she likes to tell her parents her reasons for why she chose to act the way she has, even if they seem uninterested in hearing them. Nora feels compelled to do things if she has been given good reasons. She loves to write and hopes to be an author someday.

\section{Understanding Nora}

Nora likes to be in learning environments in which ideas, concepts and thoughts are explained so she can grasp their meaning and gain understanding of them. Books are 
important to her. She likes to listen to people speak. She stays attentive to what is being said and may even write down other people's thoughts, along with her own. She is irritated if she asks a question and is not taken seriously. She wants people to understand what she thinks. She tends to try to persuade others that she is right. She enjoys the experience when conversation is heard and understood. She looks for people who listen attentively to her.

Nora may come across as argumentative and talkative. In a learning environment, she needs time to express herself and ask questions. She needs to stay with an idea until she understands it and/or agrees with it, so teachers might ask her to do some research, if she is not satisfied with a conversation. She is good at following ideas and can detect what might be missing or left unsaid. She wants to hear more about what matters to her. She also wants the freedom to ask questions and have them addressed, until the responses to them make sense to her. While she may pursue a thought for longer than others remain interested in it, she is also able to help others understand what is being communicated.

\section{Word Style and Its Teaching/Learning Goals}

The learning goal is to converse with the philosopher. Engaging in conversation with word style users develops Cognitive Literacy by helping them recognize and use healthy reason. Conceptual learning is based on the way the brain works and describes its potential for learning and growth that is built on this perceiving/conceiving foundation. Using reason helps the young find clarity as they review their worldviews and as they experience a larger world of other people's ways of perceiving/conceiving the world. As a result, they practice the following:

- Using words and reason(s) to establish conceptual relationships;

- Asking prior questions;

- Perceiving contradictions and listening to what a contradiction conveys;

- Following someone else's thinking;

- Stating one's own thinking clearly;

- Self-reflection on one's own ideas and statements;

- Using precision and accuracy to achieve conceptual clarity;

- Analyzing, comparing, contrasting, asking and responding to good questions.

Cognitive Literacy is a fully developed willingness and ability to think about the meaning of words, concepts, sentences, ideas and their inter-relatedness, until a sense of clarity is achieved. Cognitive literacy is the outcome of the peculiarly stubborn effort to get clear about something that is the heart of reason. A word style user employs reason as a natural response to solving a problem. As with Nora, word style users may alienate others who do not have the same interest in using words and concepts as precisely as she wants to do.

Strong word style users may convey they have little respect for other people's comments and thoughts. In the context of a learning environment that is intentionally inclusive of all the Styles, Nora can learn to interpret more accurately the way others try to solve problems and gain interpersonal understanding that helps improve a situation. A Style rich learning environment allows Nora to gain competence in her word orientation by developing the following skills:

- Develop clarity and clear thinking.

- Use reason, which is a stubbornly persistent effort to get clear about something (Gottlieb 2016).

- Develop conversational skills, e.g., Socratic conversation, Aristotelian Deliberation.

- Play with the meaning of words and ask good questions, as some examples:

How do concepts form?

How do conceptual analysis and informal logic work?

How do words work in relation to other words?

What does coherence look like and what practices help to build clarity?

What am I currently thinking about this or that concept? 
What am I learning about those concepts that might change what I think? What are the underlying beliefs that hold together what I disbelieve?

\section{Word Learning Environments}

To create a learning environment, provide for the study of words, so that children come to understand the meaning of important culture-shaping terms, concepts and ideas, and become precise, clear and intellectually confident about the foundation of their tradition. In addition, build on their meaning of significant concepts by exploring the world of text and by hearing other people's experience. As a result, children will make cognitive gains in understanding communal meanings, learn to discuss, reason, reflect on these meanings and bring personal experience to bear on the intellectual life of their community and eventually become reflective participants within it.

\section{Emotion Style Scenario}

Sara loves her school. It is a performing arts school and she is involved in the school's production of Wind in the Willows. She feels a sense of belonging when she is with her friends singing and dancing on stage. Her friends love her and are drawn to her warm infectious laugh but sometimes they are not sure that she still likes them. Teachers praise her beautiful voice and her ability to light up the stage. Sara often makes decisions based on how she feels and sometimes this works out well. Other times her choices leave her with regret. She comes home after school flying high on the many interactions she is had during the day. Even though she spends time telling her mom about all her relationships, she sometimes complains that she does not have anyone who feels really close to her. She has a hard time completing her homework. She calls friends on the phone or texts them during the time she said she would set aside for schoolwork. She often says she does not feel motivated. Sara knows that something is important to her if she is moved to tears or something makes her so excited she feels like dancing. Her goal in life is to make people happy.

\section{Understanding Sara}

Sara places emphasis on how people are feeling when they are together. She moves toward people if she thinks they are feeling left out, and draws them in if she can. She evaluates a learning environment positively if others are moving, laughing, singing and connecting with each other. She seems to notice quickly if someone's feelings are hurt. Sara needs to maintain pleasant emotions. She uses emotion as a currency for improving a situation. Her favorite learning environment is a large room that has a stage and plenty of musical instruments in it. A satisfying approach to learning draws her into singing, dancing and drama, and she is quite good at all three activities. She loves being in the centre of attention so she can tell if everyone is enjoying themselves and feeling involved.

Sara may come across as self-absorbed and only interested in activities that are fun. She may be restless during times that teachers or leaders are speaking to the group and she may look around to see how others are feeling. She may fidget as she focuses on other learners, and may seem uninvolved, inattentive and distracted to an adult. Sara needs others to be engaged in what is going on and to enjoy what is happening. She is relational and has skill to draw others into a game or activity and to shift what is happening so that others remain engaged and pleased with what is going on.

\section{Emotion Style and Its Teaching/Learning Goals}

The learning goal is to sing and act with the dancer to enhance Emotional Literacy by achieving self-awareness and self-regulation through mutual regulation. This is done by engaging learners in practicing:

- Emotional awareness and self-regulation;

- Expressing clear emotion and specific feelings;

- Moving, acting, role playing; 
- Learning through the Arts, music and experience;

- Playing with an understanding of a very wide range of emotions;

- Seeing the connections between emotions and actions.

Emotional Literacy is a fully developed willingness and ability to gain self-awareness and develop self-regulation, as well as accurately reading others in a way others can affirm. Sara uses emotion to draw people together but may tend to trap others due to her need to create and sustain the emotional climate she seeks to perpetuate. People who use emotion to improve a situation do not necessarily come across as emotional. They may be quiet and reflective, but their goal is to create a strong connection among people, so others want to be involved and feel valued. Strong Emotion Style users tend to seek out people who are on the margins and draw them into whatever is going on. However, they may overvalue the importance of every emotion. Not every emotion is of equal value or is worth acting on. To gain emotionally literate competency, these Style users participate in the following skills:

- Developing Self-Awareness.

- Achieving Self-Regulation:

Reflecting on self-consciousness-what is going through my mind;

Stopping thoughts that hurt me;

Managing the thoughts that I want to change;

Learning from what is happening in my own heart;

Bring my own meaning to bear on my action;

Recognize and acknowledge the meaning others make;

Deciding which emotions to act on and which not to act on;

Learning to recognize emotions in other people;

Learning to notice when to release other people from an emotional context.

\section{Emotion Learning Environments}

To create an emotionally rich environment, offer children opportunities to learn through feeling, speaking, music, art and dance. Furthermore, offer them encounters with personal narratives that cover a range of emotions and allow the young to explain what these stories mean to them. The overall goal in establishing a diverse emotional context is to help children gain self-awareness and self-regulation through healthy adult-led mutual regulation within that setting so that children come to recognize their own feelings and the feelings of others and can begin to assess their behaviour based on understanding how it impacts other people and themselves.

\section{Symbol Style Scenario}

Alex is a nine-year-old boy who attends a private elementary school, known for its high academic standards. Alex recently told his parents that he believes he does not fit in. In his opinion, teachers at his school over teach, they tell the children what to think. "They have no imagination," he told his parents. "I can't be creative. I prefer to learn by exploring mysteries, rather than reading textbooks". Alex loves stories about the Bermuda Triangle and Stonehenge. They are mysterious and allow him to wonder. His teachers tell Alex about the certainties of science and mathematics, but he cannot help wondering about the mysteries of life and the world around him. Alex often feels frustrated with the pace of his school day and wishes there was more time each day to think about things. He feels there must be more to life than what he sees. When he sits quietly on the bank of the river across from his home, he sees the wind blowing through the trees and hears the water rushing past him. He feels at peace with the world and close to God.

\section{Understanding Alex}

Alex is content to be by himself in his favorite places, which typically are in natural settings. He enjoys the quiet listening that goes along with being an observer and may seem to remain on the edges of what is happening when he is in a group. He values being more than doing, as we sometimes say. He enjoys the privacy of his own room and spends 
time in nature. He loves the hobby of being a birder and along with his dad, joined a group of adults on bird watching trips, which he is been involved in since he was quite young.

Alex may say very little, if anything, in learning environments unless leaders or teachers allow for quiet reflection and seem unhurried as they teach. He may be more content with observing an activity that other children are engaged in, but this does not mean he is not present. He has a personal listening approach that is easily misunderstood and misinterpreted as disinterest in what is going on. Alex needs time to think about words and symbols that are used to foster learning and may feel frustrated if ideas are over explained, as he puts it. A quiet, calm, reflective activity is well suited to values he places on mulling over mysteries that lie behind and within words, rituals and symbols that are being used by other people.

\section{Symbol Style and Its Teaching/Learning Goals}

The learning goal is to respond with the Mystic and to develop Imaginative Literacy by practicing the quiet, reflective, future oriented possibilities that link perception and cognition and that move people into the future. If we consider the research on spiritual experiences noted earlier, it may be that Alex would be most comfortable with the experiences listed, while other Style users may not be as comfortable. To gain Imaginative Literacy, these Style users:

- Enjoy quietness and beauty;

- Think imaginatively;

- Find stillness;

- Participate in rituals and use symbols;

- Learn through meditation, from Nature and by careful observation;

- Mull over words, symbols and practices and wonder about them.

Imaginative Literacy is a fully developed penetrating perception of whole and partial worlds, whether visible or beyond ordinary seeing and includes a capacity for making sense of other people, entities and events that may also be meaningfully communicated in various ways (e.g., in poetry, art). Imagination is central to understanding other people. Beginning to be aware of what is imaginable and what is unimaginable in one's inherited content and personal experience is a pivot point for future growth. These Style users are invited into the following skills:

- Develop moral/aesthetic sensibilities to see what is going on;

- Achieve a responsive capacity for empathy and mindfulness;

- Spiritual disciplines/traditional practices/facilitating rituals;

- Rituals built into worship and everyday life;

- Quiet wondering;

- Experiences of other whole worlds, e.g., in literature and sacred texts.

\section{Imaginative Learning Environments}

To allow for imaginative learning environments, give children time for silent wondering, experiences in nature and ritual, as well as opportunities to ruminate on the expansive narrative that structures the community, with the aim of helping children find a meaningful place within it. Communal narratives convey large issues children want and need to understand in terms of the beginning and the end of life and the specific virtues and ideals honored by that community, so they gain a sense of what it means to be a valued member. Rituals and narratives develop their imagination based on the communal worldview so that children can interpret experience meaningfully, especially the flow of loss and recovery that shapes all human learning.

\section{Action Style Scenario}

When Mark was four, he found out that some people in the world did not have clean water and were getting sick. He was surprised and knew it was not fair. How could we have so much clean water in Canada when other people did not have any? He knew he 
could do something to help. When he was five, he started to raise money to build a well in Africa. The whole idea of helping people in Africa got started when he built a little well in kindergarten while he was doing a project about pulleys and levers. He got the idea to start collecting money in his well to build a real well in Africa. Mark decided to ask his friends to help in his project and some of them did. He told his teacher he was frustrated with those in his class who did not want to participate. He was passionate about getting clean water to people who did not have it. He wanted to send money to Africa that would build three wells, three sets of latrines and hand-washing stations. He also wanted people to teach children about clean water so they would be safe. When anyone asks Mark why he works on his projects he says, "This is my passion, this is what makes me feel good".

\section{Understanding Mark}

Mark is motivated by justice and to act quickly to create solutions that solve problems he sees around him or in other parts of the world. In a classroom, he may stay on the periphery of what is going on, particularly if it is a group discussion or teaching time in a lecture format. Mark needs people to join him in his activity or get out of his way so he can do it himself, once he sees what needs to be done. If he is on the edge of what is going on, he may convey impatience and distance. When he speaks, he may tell others what needs to be done, but if responses do not come quickly, he may simply go off to do it himself, by himself.

Mark needs people to join him in his projects and values them if they follow his lead, but is frustrated if, as he puts it, all others do is talk about what needs to get done. He wants to get right down to doing what is required, as he sees it. He often asks others to help him and has strong views about how to do what he believes should be done. Mark expects people to do what they say. In a learning environment, he can seem impatient and critical. Often others may believe he is judging them if they are not doing what he thinks should happen. People may misinterpret his passion as personal criticism of them. He quickly becomes involved and passionate if others take on a project he values and that he thinks will positively impact other people or a situation.

\section{Action Style and Its Teaching/Learning Goals}

The learning goal is to accompany a change agent and to develop Social Literacy by achieving social awareness and the relational skill that will allow this Style user to learn how to maintain a healthy relational environment through practicing the following:

- Involvement in the world with those who are marginalized or in poverty;

- Acting on situations that need the improvement that these Style users identify;

- Personal engagement in improvement and change;

- Seeing the patterns in human interaction that create inequality, unfairness;

- Seeing what is there, what is not there and what could be there;

- Learning by doing, observing and being with others who are working for Justice.

Social Literacy is a rich capacity to be authentic and yet fully integrated within the community. While Mark makes enormous contributions to people and projects, he would benefit from learning skills that allow him to convey what matters to him in ways others can grasp. For Mark to acquire these skills, he needs people who walk with him and teach him on the run. Ultimately, he needs to realize that others use different ways (words, emotion, symbols) to make the world a better place. These Style users learn by practicing the following skills:

- Develop an authentic voice.

- Achieve integrative skills that allow one to remain oneself while with others.

Social Awareness based on deep self and other understanding;

Social Facility: skills that enhance social interaction;

Reflection on practice;

Attentive to expressing kindness to others while engaged in action; 
A sense of social justice and responses to individual issues that arise;

Perceiving systemic injustice and responding to ameliorate it (Bellous 2016).

\section{Social Learning Environments}

To encouragement social learning, incorporate opportunities for children to take specific, focused action to make the world a better place. These opportunities include working in situations that convey the effects of injustice on people's lives. Furthermore, create and maintain sustainable projects so that children can see first-hand the effects of poverty, and contribute to physical and mental care of people in their local community (e.g., seniors), as well as globally, as appropriate for their age group. Invite children and youth into cleaning and caring for their environment, as adults actively carry out these activities with them. As children and youth are engaged in these situations, they can identify practices that create harm, inequalities and injustices that require repair. They can act alongside competent adults as they to try to bring about a better world.

\section{Conclusions}

Spiritual care engages competent adults in the task of attending to the human spirit of the young. The practice of spiritual care welcomes and is hospitable to commonalities and uniqueness among children and youth. This article provides patterns of spiritual care that build a secure foundation for teaching children to be members of a religious tradition eventually. If adults understand how concepts form, including God concepts, and how these concepts remain open to a child's capacity to continue exploring the world, religious instruction ideally meets a child's deepest, most enduring spiritual needs-needs that, when met, will take the young into maturity as balanced and healthy believers (Taylor 2007).

The purpose of spiritual care with the young is to focus on their humanity and situate their education in a framework built upon a comprehensive approach to human development. The four types of literacy offer a broad and balanced approach to the intellectual, emotional, imaginative and social development of children that allows them to live in a secular world that has as its background the cultural and religious diversity and complexity that characterizes the time in which we are living (Taylor 2007). The cultural, religious and social diversity of the twenty-first century requires adults to attend to children fully so the young can flourish within religions they welcome, understand, and in which they participate personally.

At the outset of the article, there was a reference to the confusing times in which we live, which are made more confusing by COVID 19. Furthermore, adolescence is always a turbulent time. As we look back on this historic moment, we will continue to reflect on its controversies and its many negative effects on the young. Spiritual care is an antidote to the abandonment youth may experience during the turbulence of adolescence, if they believe everything they happen to think, if they act on every emotion as if each one is of equal value, if they are caught in the tunnel vision of a narrow, high-walled imagination, and if they are without the humanizing benefits of realizing how they can make the world a better place. Spiritual care, as a literacy-based approach, introduces adults into the adventure of accompanying the young as they become intellectually, emotionally, imaginatively and socially astute and well-integrated, and learn to be authentic participants within a religious tradition, as well as in the world.

Funding: This research received no external funding.

Conflicts of Interest: The author declares no conflict of interest.

\section{References}

Arendt, Hanna. 1978. The Life of the Mind. New York: Harcourt, Brace, Jovanovich, Inc.

Aristotle. 1980. The Nicomachean Ethics. Translated by David Ross. Oxford: Oxford University Press.

Baudrillard, Jean. 1993. The Transparency of Evil: Essays on Extreme Phenomena. Translated by James Benedict. London: Verso. 
Bayard, Carolyn, and Joyce E. Bellous, eds. 1999. Emmanuel Levinas: The Ethics of Responsibility for Philosophy Today Volume 43, Number 2/4 (Summer). [Essayists include George Hansel, Enrique Dussel, Luiz Carlos Sussin, Jan Sokol, Zygmunt Bauman and Richard A. Cohen.]. Chicago: Philosophy Documentation Center.

Bellous, Joyce E. 2015. Educating Faith: An Approach to Christian Formation. Edmonton: Tall Pine Press.

Bellous, Joyce E. 2016. Learning Social Literacy. Edmonton: Tall Pine Press.

Bellous, Joyce E., and Margaret Clark. 2022. Thick Listening at Thin Moments: Theoretical Groundwork for Spiritual Care Practice. Edmonton: Tall Pine Press.

Bellous, Joyce E., David Csinos, and Denise Peltomaki. 2009a. Spiritual Styles Assessment—Adult. Edmonton: Tall Pine Press.

Bellous, Joyce E., David Csinos, Denise Peltomaki, and Karen Bellous. 2009b. Spiritual Styles Assessment—Children. Edmonton: Tall Pine Press.

Bellous, Joyce E. 1996. Jean Baudrillard: Reclaiming EvilTalk. Lire Baudrillard aujourd'hui/Reading Baudrillard Now for the Journal of recherches semiotiques/Semiotic Inquiry 16: $27-47$.

Bloom, Harold. 1998. Shakespeare: The Invention of the Human. New York: Riverhead Books.

Bowlby, John A. 1988. Secure Base: Parent-Child Attachment and Healthy Human Development. New York: Basic Books.

Caygill, Howard. 1995. A Kant Dictionary. Malden: Blackwell Publishers.

Clinton, Jean. 2020. Love Builds Brains. Edmonton: Tall Pine Press.

Coles, Robert. 1989. The Call of Stories. Boston: Houghton Mifflin Company.

Dewey, John. 1980. Art as Experience. New York: A Perigee Book.

Erikson, Erik. 1950. Eight Ages of Man. In Childhood and Society. New York: W.W. Norton \& Company.

Freud, Sigmund. 1961. The Future of an Illusion. New York: W.W. Norton and Company.

Gendlin, Eugene T. 1962. Experiencing and the Creation of Meaning. New York: The Free Press of Glencoe.

Goleman, Daniel. 1995. Emotional Intelligence. New York: Bantam Books.

Goleman, Daniel. 2006. Social Intelligence. New York: Bantom Books.

Gottlieb, Anthony. 2016. The Dream of Reason. New York: W.W. Norton and Company.

Gramsci, Antonio. 2011. Prison Notebooks. New York: Columbia University Press.

Hay, David. 2007. Something There: The Biology of the Human Spirit. Philadelphia: Templeton Foundation Press.

Hay, David, and Rebecca Nye. 1998. The Spirit of the Child. London: Fount.

Hayek, Friedrich A. 1976. The Sensory Order: An Inquiry into the Foundations of Theoretical Psychology. First published 1952.

Hebb, Donald. 1980. Essays on Mind. New York: Psychology Press.

James, William. 1971. The Varieties of Religious Experience. London: The Fontana Library.

Kagan, Jerome. 1998. Galen's Prophecy. New York: Routledge.

Kegan, Robert. 1982. The Evolving Self: Problem and Process in Human Development. Cambridge: Harvard University Press.

Kegan, Robert. 1994. In Over Our Heads: The Mental Demands of Modern Life. Cambridge: Harvard University Press.

Klein, Josephine. 1987. Our Need for Others and Its Roots in Infancy. London: Tavistock Publications.

Korn Ferry Hay Group. 2011. Emotional and Social Competency Inventory. Available online: www.haygroup.com (accessed on 5 September 2021).

Miller, Lisa. 2015. The Spiritual Child: The New Science on Parenting for Health and Lifelong Thriving. New York: St. Martin's Press.

Penfield, Wilder. 1975. The Mystery of the Mind: A Critical Study of Consciousness and the Human Brain. Princeton: Princeton University Press.

Plato. 1956. Great Dialogues of Plato: The Republic, Apology, Crito, Phaedo, Ion, Meno. Translated by William Henry Denham Rouse. New York: New American Library.

Pratt, James Bissett. 1956. The Religious Consciousness. New York: The MacMillan Company.

Rizzuto, Ana-María. 1979. The Birth of the Living God. Chicago: University of Chicago Press.

Rizzuto, Ana-María. 1998. Why Did Freud Reject God? New Haven and London: Yale University Press.

Shrier, Abigail. 2020. Irreversible Damage: The Transgender Craze Seducing Our Daughters. New York: Regnery Publishing.

Soh, Debra. 2020. The End of Gender. New York: Simon and Schuster, Inc.

Spencer, Lyle M., and Signe M. Spencer. 1993. Competence At Work: Models for Superior Performance. New York: John Wiley and Sons.

Stern, Daniel. 1985. The Interpersonal World of the Infant. New York: Basic Books.

Stern, Daniel. 2004. The Present Moment in Psychotherapy and Everyday Life. London: W.W. Norton \& Company.

Taylor, Charles. 2007. The Secular Age. London: Belknap.

Winnicott, Donald Woods. 1971. Playing and Reality. London: Tavistock Publications. 